\title{
Quantifying human and environmental viral load relationships amidst mitigation strategies in a controlled chamber with participants having COVID- 19
}

\section{Hooman Parhizkar}

Institute for Health in the Built Environment, University of Oregon https://orcid.org/0000-0003-0392-9459

\section{Leslie Dietz}

Biology and the Built Environment Center, University of Oregon https://orcid.org/0000-0002-5623-1524

\section{Andreas Olsen-Martinez}

Biology and the Built Environment Center, University of Oregon

\section{Patrick Horve}

Biology and the Built Environment Center, University of Oregon https://orcid.org/0000-0002-9318-9249

\section{Liliana Barnatan}

Biology and the Built Environment Center, University of Oregon

Dale Northcutt

University of Oregon

Kevin Van Den Wymelenberg ( $\sim$ kevinvdw@uoregon.edu )

kevinvdw@uoregon.edu

\section{Article}

Keywords: SARS-CoV-2, aerosol, infectious disease, airborne, particles, ventilation, humidification, filtration

Posted Date: September 29th, 2021

DOI: https://doi.org/10.21203/rs.3.rs-940891/v1

License: (c) (i) This work is licensed under a Creative Commons Attribution 4.0 International License. Read Full License

Version of Record: A version of this preprint was published at Clinical Infectious Diseases on January 6th, 2022. See the published version at https://doi.org/10.1093/cid/ciac006. 


\section{Abstract}

Several studies indicate that COVID-19 is primarily transmitted within indoor spaces. Therefore, environmental characterization of SARS-CoV-2 viral load with respect to human activity, building parameters, and environmental mitigation strategies is critical to combat disease transmission. We recruited 11 participants diagnosed with COVID-19 to individually occupy a controlled chamber and conduct specified physical activities under a range of environmental conditions; we collected human and environmental samples over a period of three days for each participant. Here we show that increased viral load, measured by lower RNA cycle threshold $\left(\mathrm{C}_{\mathrm{T}}\right)$ values, in nasal samples is associated with higher viral loads in environmental aerosols and surfaces captured in both the near field $(1.2 \mathrm{~m})$ and far field $(3.5 \mathrm{~m})$. At ambient conditions with $\sim 0$ Air Changes per Hour (ACH), near field measurements showed a higher particulate matter abundance and carbon dioxide $\left(\mathrm{CO}_{2}\right)$ concentration as compared to far field measurements. We also found that aerosol viral load in far field is correlated with the number of particulates within the range of $1 \mu \mathrm{m}-2.5 \mu \mathrm{m}$. Furthermore, increased ventilation and filtration are associated with lower environmental viral loads, and higher relative humidity is associated with lower aerosol viral loads and higher surface viral loads, consistent with an increased rate of particle deposition. Data from near field aerosol trials with high expiratory activities suggest that respiratory particles of smaller sizes $(0.3 \mu \mathrm{m}-1 \mu \mathrm{m})$ best characterize the variance of near field aerosol viral load. Moreover, our findings indicate that building operation practices such as ventilation, filtration, and humidification substantially reduce the environmental aerosol viral load, and therefore inhalation dose, and should be prioritized to improve building health and safety.

\section{Introduction}

Severe acute respiratory syndrome coronavirus 2 (SARS-CoV-2), the causative agent of Coronavirus disease 2019 (COVID-19), has resulted in 230,418,451 confirmed cases with more than 4,724,876 deaths globally, as of 24 September $2021^{1}$. There is substantial evidence that inhalation of aerosol particles containing viable SARS-CoV-2 virions is the primary route of human-to-human transmission ${ }^{2-7}$. Modeling of the impact of nonpharmaceutical interventions on the probability of COVID-19 infection and mortality rate through public health ${ }^{8,9}$ and engineering perspectives ${ }^{10}$ suggests that indoor congregation is the primary driver for COVID-19 disease transmission ${ }^{11}$. Therefore, better understanding and quantifying the relationship of human factors, design, and building operation practices on the abundance and dispersion of viral load in indoor spaces is necessary to combat disease transmission and provide environments for safe indoor congregation ${ }^{12}$.

Breathing and talking are some of the human expiratory activities that have been studied to determine how these activities are associated with concentrations of viral pathogens. These studies have contributed valuable information about the viral load of size fractionated aerosols $5,13,14$. In addition to human expiratory factors, indoor space design and engineering practices such as ventilation, filtration, and humidity control may influence the abundance and infectious fraction of the environmental viral load, and therefore reduce inhalation dose ${ }^{14-20}$. However, these indoor environmental interventions need to be studied independently 
through controlled experiments to quantify their impacts, while minimizing confounding variables, especially with regard to aerosols that may contain SARS-CoV-2.

In this research, we sought to better understand viral abundance and dispersion associated with differing degrees of expiratory activity, ventilation, filtration, and humidification through controlled experiments in a quasi-field setting. We measure viral RNA of SARS-CoV-2 using quantitative reverse-transcription polymerase chain reaction (qRT-PCR) techniques as a proxy of viral load in humans and environmental aerosols and surfaces. We studied 11 human participants that were diagnosed with COVID-19 in a controlled chamber measuring $4.3 \mathrm{~m}$ in length, $2.8 \mathrm{~m}$ in width, and $2.5 \mathrm{~m}$ in height $\left(28.04 \mathrm{~m}^{3}\right)$. Our research protocol comprised a 3-day study for each participant in which human activity and environmental factors (ventilation rate, in-room filtration, humidity control) were studied as independent variables. In summary we found statistically significant:

1. positive relationships between viral load (RNA) found in human specimens and paired aerosol and surface samples at $\sim 0 \mathrm{ACH}$ and ambient conditions for sitting and standing trials (routine trials) as well as trials with high expiratory activities (coughing, speaking, and speaking loudly);

2. positive relationship between viral load in near field aerosols captured during periods of higher expiratory activity and near field particles of $0.3 \mu \mathrm{m}-1 \mu \mathrm{m}, 1 \mu \mathrm{m}-2.5 \mu \mathrm{m}$, and $10 \mu \mathrm{m}-25 \mu \mathrm{m}$ in size, but no statistical significance for $2.5 \mu \mathrm{m}-10 \mu \mathrm{m}$ particles;

3. increased $\mathrm{CO}_{2}$ concentrations and particulates in the range of $1-5 \mu \mathrm{m}$ measured in the near field as compared to the far field for routine trials;

4. positive relationship between aerosol viral load in the far field and the number of corresponding far field particles detected in the range of 1-2.5 $\mu \mathrm{m}$;

5. inverse relationships between viral load found in aerosols and degree of ventilation, as well as in-room filtration;

6. relationships between viral load and degree of relative humidity $(\mathrm{RH})$; whereby higher $\mathrm{RH}$ is associated with lower viral load in aerosol samples and higher viral load in select surface samples, consistent with increased particle deposition on surfaces.

\section{Results}

A rapid deployment modular unit (RDM) was used as an environmentally controlled chamber (Figure 1) for this human participant study during Winter and Spring 2021. The study population contained four males and seven females between the age of 18 and 24 (Supplemental table 1). Two high-flow (200 L/min) AerosolSense air samplers (Thermo Fisher Scientific) were placed approximately 1.2 and 3.5 meters from the participants. At the end of each study period, samples from the air samplers (near, far), high-touch surfaces (phone, computer, chair), settling plates (near, far), and human specimens (shallow nasal) were collected and transported to a BSL-2 laboratory on the University of Oregon campus in Eugene, Oregon, USA for further molecular analysis.

Table 1 Study plan for participants that were diagnosed with COVID-19; S1 and S2 refer to experimental setup 1 and setup 2 
Set-up 1. Physical activity

\begin{tabular}{|c|c|c|c|}
\hline s1 & 10 coughs in 1 minute & 10 coughs in 1 minute & 10 coughs in 1 minute \\
\hline S1 & Speak for $\underline{5 \text { minutes }}$ & Speak for $\underline{5 \text { minutes }}$ & Speak for $\underline{5 \text { minutes }}$ \\
\hline s1 & Speak loudly for $\underline{5 \text { minutes }}$ & Speak loudly for $\underline{5 \text { minutes }}$ & Speak loudly for $\underline{5 \text { minutes }}$ \\
\hline S2 & 1-hour regular sitting & 1-hour regular sitting & 1-hour regular sitting \\
\hline S2 & 1-hour standing & 1-hour sitting at $\sim 9 \mathrm{ACH}$ & 1-hour sitting at low RH \\
\hline S2 & $\underline{30-m i n}$ sitting silently & 1-hour sitting at $\sim 3 \mathrm{ACH}$ & 1-hour sitting at low RH \\
\hline S2 & $\underline{30-m i n}$ sitting speaking & 1-hour sitting at $\sim 9 \mathrm{ACH}$ & 1-hour sitting at high $\mathrm{RH}$ \\
\hline S2 & $\underline{15-m i n}$ walking on treadmill & 1-hour sitting at $\sim 4.5 \mathrm{ACH}$ & 1-hour sitting at high $\mathrm{RH}$ \\
\hline S2 & & 1-hour sitting with HEPA filtr & \\
\hline
\end{tabular}

Trials were conducted in two different set-ups over three days. Trials with a S1 suffix indicate Setup-1 where both air samplers were placed next to each other for short duration and higher expiratory tests (Figure 1a). During cough trials, participants were instructed to conduct 10 uncovered coughs into an area over the air samplers, particle counters (TSI AeroTrak 9306), and $\mathrm{CO}_{2}$ (Onset HOBO MX1102A) sensors. During speak tests, participants were instructed to conduct continuous vocalization using a standardized CDC defined passage $^{21}$ (Supplemental document, appendix A) for 5 minutes with normal and higher amplitude at their discretion, respectively ${ }^{22}$. A S2 suffix indicates trials where participants conducted routine activities at a desk, including sitting and standing, sitting silently, sitting and participating in an online conference meeting, or were invited to walk on treadmill (physical activity day) (Figure 1b).

\section{Near and far field aerosol samples and paired human specimens}

To quantify the relationship between viral loads (RNA copies) in human nasal and aerosol samples, we paired the outcome of each aerosol sample collected with its corresponding shallow nasal sample for both near and far AerosolSense samplers during trials when participants were sitting or standing for one hour at $\sim 0 \mathrm{ACH}$ under typical ambient conditions without environmental interventions (routine trials). Figure 2a shows the relationship between nasal viral load and near field and far field aerosol viral load for all routine trials. Note that negative samples are defined with a value of $40 \mathrm{C}_{\mathrm{T}}$.

The coefficients associated with significant regression models presented in Figure 2a indicate that an increase in viral load equivalent to $-1 \mathrm{C}_{\mathrm{T}}$ in human nasal samples is associated with increased near field viral load of $-0.32639 \mathrm{C}_{\mathrm{T}}\left(\mathrm{R}^{2}=0.2276, P=0.001092\right)$ and increased far field viral load of $-0.4014 \mathrm{C}_{\mathrm{T}}\left(\mathrm{R}^{2}=0.4026\right.$, $P=1.721 \mathrm{e}-06)$. The difference of means between the aerosol $\mathrm{C}_{\mathrm{T}}$ value of near field and far field aerosol samples was $1.0583 \mathrm{C}_{\mathrm{T}}$, whereas far field samples represent lower viral load, however the paired t-test 
differentiating near field and far field samples was not significant $(P=0.05955)$ (Figure $2 \mathrm{~b}$, note that black solid horizontal line represents median in all box plots). Therefore, we also report the significant coefficient for all nasal and aerosol samples in routine trials which indicates that an increase in viral load equivalent to $-1 C_{T}$ in nasal samples is associated with an increase in room aerosol viral load of $-0.36216 C_{T}\left(R^{2}=0.3119\right.$, $P=1.675 \mathrm{e}-08$, Supplemental figure 1 ). Based upon qRT-PCR theory, a $-1 \mathrm{C}_{\mathrm{T}}$ difference is approximately equivalent to double the viral load ${ }^{23}$. To our knowledge this is the first reported relationship between environmental aerosol viral load and human viral load in a controlled environment $\left(28,040 \mathrm{~L}^{3} \mathrm{room}, \sim 0 \mathrm{ACH}\right.$, one-hour trials, single COVID-19 positive individual).

In addition to these viral dispersion characteristics, among all routine trials, we found a statistically significant difference between the mean $\mathrm{CO}_{2}$ concentration recorded at near field and far field, whereas $\mathrm{CO}_{2}$ concentrations of near field were 80 PPM higher than in the far field $(P=0.0004009)$ (Figure 2c). Moreover, analysis of particles for routine trials indicates that there is a statistically significant difference between the number of particles collected in the range of $1-5 \mu \mathrm{m}$ within the near field versus the far field, as summarized in Figure 2d (expanded in Supplemental figure 2). No statistical difference between near and far field was observed for particles in the range of $0.3-1$ and $5-25 \mu \mathrm{m}$ (Figure $2 \mathrm{~d}$ ) for routine trials.

We explored the relationships between aerosol viral load, particle counts, and $\mathrm{CO}_{2}$ concentration for all routine trials. We did not find any significant correlation between near field aerosol viral load and the corresponding number of near field particles for any size bin for routine trials. As shown in Figure $2 \mathrm{e}$, we identified a significant relationship between aerosol viral load and far field particle counts within the size bin 1-2.5 $\mu \mathrm{m}$. The significant coefficient in Figure $2 \mathrm{e}$ indicates that an increase in far field aerosol viral load equivalent to -1 $\mathrm{C}_{\mathrm{T}}$ is associated with $\sim 27$ more particles in the range of $1-2.5 \mu \mathrm{m}\left(\mathrm{R}^{2}=0.1112, P=0.04313\right)$ in the far field. We report a statistically significant positive correlation between the average far field $\mathrm{CO}_{2}$ concentration and the number of particles of $0.3 \mu \mathrm{m}-3 \mu \mathrm{m}$ in far field for routine trials (Supplemental figure 3). Far field data from routine trials suggest that particles of $1 \mu \mathrm{m}-2.5 \mu \mathrm{m}$ best characterize the variance of far field aerosol viral load. Taken together, our findings about far field particles of $1 \mu \mathrm{m}-2.5 \mu \mathrm{m}$, far field $\mathrm{CO}_{2}$ concentration and particles of $0.3 \mu \mathrm{m}-3 \mu \mathrm{m}$, and the difference between near and far field particles of $1 \mu \mathrm{m}-5 \mu \mathrm{m}$ provide further evidence of the importance of fine aerosols in the potential for COVID-19 disease transmission in both near and far fields.

\section{High-touch surfaces, settling plates, and paired human specimens}

Human specimens were compared to paired samples collected from the participants' phone (screen), computer (adjacent to keyboard), and chair (described as high-touch surfaces), and from near field settling plates (on participant's desk) and far field plates (adjacent to far field air sampler). Figure 3a illustrates the significant linear regressions for the viral load (RNA) on each high-touch surface relative to paired nasal samples. Figure $3 \mathrm{~b}$ illustrates the significant linear regressions for viral load in settling plates (near and far) relative to paired nasal samples. There are no significant differences between the viral loads found in near 
field and far field setting plates, nor are there significant differences between any of the high-touch surfaces (Supplemental figures $4 \& 5$ ). Figure $3 \mathrm{c}$ illustrates the significant regressions for all sampling types relative to human nasal samples within a single figure and indicate that high-touch surfaces and aerosol samples have higher viral loads than settling plate surfaces.

\section{High expiratory activity, particles, and aerosol viral load}

We find a significant correlation between aerosol viral load associated with high expiratory activities and paired nasal samples whereas an increase in viral load equivalent to $-1 C_{T}$ in human nasal samples is associated with increased immediate field ( $<1 \mathrm{~m}$, Figure 1a) aerosol viral loads as follows: $-0.1895 \mathrm{C}_{\mathrm{T}}\left(\mathrm{R}^{2}=\right.$ $0.09058, P=0.0225)$ for 1 -minute cough tests, $-0.2713 \mathrm{C}_{\mathrm{T}}\left(\mathrm{R}^{2}=0.1979, P=0.00115\right)$ for 5 -minute speaking tests, and $-0.2296 C_{T}\left(R^{2}=0.1796, P=0.00141\right)$ for 5 -minute speaking loudly tests (Supplemental figure 6 ). Furthermore, we find a significant positive relationship between the mean number of immediate field particles during high expiratory activities (Setup 1) in the size ranges $0.3 \mu \mathrm{m}-1 \mu \mathrm{m}$ (Figure $4 \mathrm{a}$ ), $1 \mu \mathrm{m}-2.5 \mu \mathrm{m}$ (Figure 4b), and $10 \mu \mathrm{m}-25 \mu \mathrm{m}$ (Figure 4e) and the viral load in the immediate field aerosols, while the other particle size bins are not significant (Figure 4).

Interestingly, the $0.3 \mu \mathrm{m}-1 \mu \mathrm{m}$ size bin indicates the highest correlation coefficient between immediate field particle counts and immediate field aerosol viral load. While the relationship between the particles of $1 \mu \mathrm{m}$ $-2.5 \mu \mathrm{m}$ and immediate field viral load is significant, there is no significant relationship found for $2.5 \mu \mathrm{m}-3$ $\mu \mathrm{m}, 3 \mu \mathrm{m}-5 \mu \mathrm{m}$ and $5 \mu \mathrm{m}-10 \mu \mathrm{m}$.

Among high expiratory trials, we observed an increase in immediate field viral load equivalent to $-1 \mathrm{C}_{\mathrm{T}}$ to be associated with an increase of $\sim 1000$ particles of the size $0.3 \mu \mathrm{m}-1 \mu \mathrm{m}$, and an increase in $\sim 100$ particles of the size $1 \mu \mathrm{m}-2.5 \mu \mathrm{m}$, and $\sim$ one particle of the size $10 \mu \mathrm{m}-25 \mu \mathrm{m}$ in the immediate field. It is important to stress that these results are relevant to immediate field particulates dominated by bioaerosols.

Our findings for immediate field trials support previous research in which SARS-CoV-2 RNA was identified in fine particles ${ }^{5}$. While we did not find any statistically significant relationship between aerosol viral load and particle counts of $5 \mu \mathrm{m}-25 \mu \mathrm{m}$ during routine trials in the near field $(1.2 \mathrm{~m})$ or the far field $(3.5 \mathrm{~m})$, during immediate field $(<1 \mathrm{~m})$ high expiratory trials we identified a significant relationship for large particles $(10 \mu \mathrm{m}$ $-25 \mu \mathrm{m})$ and immediate field aerosol viral load; we hypothesize that may be due to immediate field respiratory droplets prevalent in high expiratory activities ${ }^{11,13,24}$.

\section{The impact of ventilation and filtration on aerosol and surface viral load}

Indoor air exchange rate, measured in Air Changes per Hour (ACH), has previously been demonstrated to reduce indoor particulates and therefore hypothesized to reduce the concentration of viral aerosols, 
corresponding inhalation dose, and consequently the probability of indoor occupants acquiring infection ${ }^{25-}$ 27 . Few studies have measured the relationship between ventilation, filtration and aerosol viral load ${ }^{28}$. Therefore, we investigated the impact of alternate air exchange rates, using $100 \%$ outside air (OSA) and filtration levels during removal mechanism trials. As shown in Table 1, the removal mechanism day began with a baseline $\sim 0 \mathrm{ACH}$ trial, followed by four 100\% OSA ventilation trials (two at $~ 9 \mathrm{ACH}$ and two at $~ 3-4.5$ $\mathrm{ACH}$ ) provided by an exhaust fan (fitted with HEPA filter for infection control). Thereafter, a single trial with two in-room HEPA filters (without OSA) was conducted. All removal mechanism trials and the $\sim 0 \mathrm{ACH}$ control trials were conducted for a duration of one hour. We found a significant difference between control trials and all removal mechanism trials $(P=0.029$, Figure $5 a)$. In Figure 5 a we show a significant difference between control trials and paired removal mechanism trials, while in Figure $5 \mathrm{~b}$ we show a significant correlation for all control trials at $\sim 0 \mathrm{ACH}$ and all ventilation trials with $100 \% \mathrm{OA}$ organized by mean $\mathrm{CO}_{2}$ concentration. Trials with less than $\sim 4.5 \mathrm{ACH}$ (including $\sim 0 \mathrm{ACH}$ trials) were associated with significantly higher aerosol viral loads in the near field when compared with trials greater than $\sim 9 \mathrm{ACH}$, with a mean difference of $-3.6 \mathrm{C}_{\mathrm{T}}(\mathrm{P}=0.037$, unpaired t-test, Figure $5 \mathrm{c}$ ). Even though the mean difference of aerosol viral load in the far field for trials with less than $\sim 4.5 \mathrm{ACH}$ (including $\sim 0 \mathrm{ACH}$ trials) was higher than trials with greater than $\sim 9 \mathrm{ACH}$, we did not observe a statistically significant difference for far field aerosol viral load $(P=0.085$, unpaired t-test, Figure 5c). When examining total room aerosol viral load (near field and far field together), we report that trials with less than $\sim 4.5 \mathrm{ACH}$ (including $\sim 0 \mathrm{ACH}$ trials) were associated with statistically higher viral load than trials with greater than $\sim 9 \mathrm{ACH}$, with a mean difference of $-3.2 \mathrm{C}_{\mathrm{T}}(\mathrm{P}=0.01153$, unpaired t-test, supplemental figure 9). Our research provides further evidence that improved ventilation is beneficial for both near field and far field aerosol viral load. Given these relationships within this room (Figure $5 b$ ), ventilation trials indicate that an increase in $~ 128$ PPM of $\mathrm{CO}_{2}$ concentration corresponds with an increase in aerosol viral load equivalent to $-1 \mathrm{C}_{\mathrm{T}}$, thus, approximately a doubling of the viral load. Moreover, filtration trials indicate that there is a significant difference between trials with only in-room HEPA filtration $\left(\sim 1000 \mathrm{~m}^{3} / \mathrm{hr}\right)$ and paired control trials at $\sim 0 \mathrm{ACH}$, whereas HEPA trials have lower viral load equivalent to $3.240741 \mathrm{C}_{\mathrm{T}}(P=0.029)$, thus, approximately an order of magnitude reduction (Figure $5 \mathrm{~d}$ ).

Our results provide evidence that increased air exchange ( 9 ACH with 100\% OSA) or in-room HEPA filtration $\left(\sim 1000 \mathrm{~m}^{3} / \mathrm{hr}\right)$ yields reduced aerosol viral load, and reason therefore suggests these measures are likely to reduce inhalation dose and the probability of infection in indoor spaces. We found no statistical difference between aerosols captured during control trials with $\sim 0 \mathrm{ACH}$ and those with $\sim 3-4.5 \mathrm{ACH}$; however, this may be related to limitations in sample size. Among three types of high-touch surfaces collected in this study, increased $\mathrm{ACH}$ was associated with lower viral load on participant's computers, with a mean difference of $4.033908 \mathrm{C}_{\mathrm{T}}(P=0.002323)$ whereas phone and chair samples showed no significant difference with air exchange rate (Supplemental figure 10).

\section{Relative humidity and aerosol viral load}

Relative humidity is hypothesized to impact aerosol pathogens and disease transmission in three ways; (1) improved human immune response ${ }^{26}(2)$ reduced viability in aerosols at relative humidity between $40-$ 
$60 \%{ }^{11,15}$, and (3) increased particle deposition ${ }^{29}$. The structure and behavior of aerosol pathogens, specifically particle size, settling rate, and diffusion, are each affected by relative humidity ${ }^{29,30}$. In this study, we aimed to measure environmental viral load at different relative humidity conditions. Two dehumidifiers and two humidifiers were used to regulate relative humidity to low and high levels during the "relative humidity" trials. All relative humidity trials were conducted for 1-hour. Each participant's relative humidity day started with a 1-hour control trial with $\sim 0 \mathrm{ACH}$ and relative humidity at ambient conditions, followed by two 1hour dehumidification trials and two 1-hour humidification trials. Room aerosol $\mathrm{C}_{\mathrm{T}}$ values were paired with mean relative humidity values (ranging from $20-70 \%$ ) recorded for each trial.

Relative humidity trials indicate that an increase of $\sim 11.85 \%$ in relative humidity corresponds with a decrease in aerosol viral load equivalent to $1 \mathrm{C}_{\mathrm{T}}(\mathrm{p}=0.008)$, thus, approximately a $50 \%$ reduction in aerosol viral load, as shown in (Figure 6a). Similarly, an increase of $\sim 10.02 \%$ in relative humidity corresponds with an increase in surface (chair, computer, phone) viral load equivalent to $-1 C_{T}(p=0.01)$ as shown in Figure $6 c$, consistent with increased particle deposition. Figure $6 \mathrm{~b}$ shows the significant decrease in aerosol viral load equivalent to $3.28908 \mathrm{C}_{\mathrm{T}}$ (paired t-test, $P=0.0002643$ ) for humidification trials as compared to dehumidification trials. Conversely, Figure $6 \mathrm{~d}$ shows the significant increase in computer surface viral load equivalent to $-2.873077 \mathrm{C}_{\mathrm{T}}$ (paired t-test, $P=0.01593$ ) for humidification trials as compared to dehumidification trials.

This is one of the first studies that investigated the role of relative humidity on viral RNA in aerosols and surfaces in a realistic setting. Our results suggest that increased relative humidity corresponds with decreased viral load in aerosols and increased viral load on select indoor surfaces, consistent with an increased rate of particle deposition. Since several studies have demonstrated that there is a substantially higher risk for aerosol mediated transmission than fomite mediated transmission ${ }^{31}$, active humidity control (including humidification, or reduced dehumidification) could be implemented to reduce aerosol mediated COVID-19 transmission risk reduction in indoor spaces. Of course, humidification controls must be properly maintained and managed to avoid condensation and mold propagation.

\section{Limitations}

All participants were given the opportunity to opt out of the study at any time, thus two subjects only completed the first day of study. There were some modest inconsistencies between trial durations in order to accommodate participants' needs. Not all participants walked on the treadmill, and some walked at different speeds or for different durations. While this was an extensive study design, conducted over three days per participants, the total number of unique participants $(n=11)$, and limited age range (18-24 years of age) of participants, presents some limitations to generalizability. RNA samples were not assessed for viability.

\section{Method}


Biological protocols were reviewed and approved by Advarra Institutional Biosafety Committee (IBC) (Protocol \#PROTO202000132). Advarra IBC is an authorized external IBC for the University of Oregon and is registered with the National Institute of Health $(\mathrm{NIH})$. Human participant protocols were reviewed and approved by the University of Oregon Institutional Review Board (IRB) (Protocol \#12292020).

\section{Participant Recruitment}

University of Oregon COVID-19 protocols require individuals living in the university residence halls to spend their isolation period at an off-campus quarantine dormitory room for 14 days. Individuals positive for COVID19 were identified through the University of Oregon Monitoring and Assessment Program (MAP). Following transfer to the isolation dormitory, individuals were recruited into the program to conduct a 3-day study at the RDM which was located in the dormitory parking lot. All participants volunteered to conduct different activities involved with this study with no penalty associated with leaving the research at any time.

\section{RDM layout}

The interior volume of the RDM was $28,080 \mathrm{~L}$. Interior temperature was maintained at $22^{\circ} \mathrm{C}+/-4{ }^{\circ} \mathrm{C}$ with three portable electric resistance heaters. Relative humidity was adjusted using two portable humidifiers and two dehumidifiers, respectively. Outdoor $\mathrm{ACH}$ of $\sim 3-4.5$ and $\sim 9$ were provided through a HEPA filtered (CleanShield HEPA 550, ALORAIR) exhaust air removal from the RDM with make-up air via infiltration and an operable window that opened during maximum ventilation trials. Filtration was provided with two in-room HEPA filters with combined Clean Air Delivery Rate (CADR) of 1000 (600 Cubic Feet per Minute) .

Temperature, $\mathrm{RH}$, and $\mathrm{CO}_{2}$ were monitored and recorded using multiple data loggers (Onset HOBO MX1102A). Particles were collected at six cut point size bins as follows: $0.3 \mu \mathrm{m}-1 \mu \mathrm{m}, 1 \mu \mathrm{m}-2.5 \mu \mathrm{m}, 2.5 \mu \mathrm{m}-3 \mu \mathrm{m}, 3 \mu \mathrm{m}$ $-5 \mu \mathrm{m}, 5.0 \mu \mathrm{m}-10 \mu \mathrm{m}$ and $10 \mu \mathrm{m}-25 \mu \mathrm{m}$, using 3 particle counters (TSI Aerotrak 9306-V2). Exhaust air flow rate was confirmed using an anemometer (Omega HHF92A CFM Master II) and later through analysis of $\mathrm{CO}_{2}$ concentration during routine and removal mechanism trials. After each experimental trial, air in the RDM was filtered at $+30 \mathrm{ACH}$ for $10+$ minutes using a CleanShield HEPA 550 (AlorAir) fitted with a HEPA filter as well two in-room HEPA filters.

\section{Sample Collection}

Samples were collected 8-12 times throughout a day as follows:

Day 1-Physical activity day ( O ACH, room condition):

1. 10-cough test via S1 set-up (Figure 1a) for 1 minute.

2. Speaking from a Center for Disease Control (CDC) approved passage (Supplemental document, appendix A) ${ }^{21}$ at normal voice amplitude via S1 (Figure 1a) for 5 minutes.

3. Speaking from a CDC approved passage (Supplemental document, appendix $A)^{21}$ at higher voice amplitude via S1 (Figure 1a) for 5 minutes.

4. Sitting and conducting daily routine activities on the office desk via S2 (Figure 1b) for 1-hour.

5. Standing and conducting daily routine activities on the office desk via S2 (Figure 1b) for 1-hour. 
6. Sitting and conducting daily routine activities on the office desk via S2 (Figure 1b) for 1-hour.

7. Sitting silently via S2 (Figure 1b) for 30 minutes.

8. Sitting and mimicking a video conference meeting via S2 (Figure 1b) for 30 minutes.

9. Walking on treadmill for 15 minutes.

Day 2-Air exchange practice day (room condition):

1. 10-cough test via S1 set-up (Figure 1a) for 1 minute.

2. Speaking from a CDC approved passage (Supplemental document, appendix $A)^{21}$ at normal voice amplitude via S1 (Figure 1a) for 5 minutes.

3. Speaking from a CDC approved passage (Supplemental document, appendix $A)^{21}$ at higher voice amplitude via S1 (Figure 1a) for 5 minutes.

4. Sitting and conducting daily routine activities on the office desk via S2 (Figure 1b) for 1-hour at $\sim 0 \mathrm{ACH}$.

5. Sitting and conducting daily routine activities on the office desk via S2 (Figure 1b) for 1-hour at $\sim 9 \mathrm{ACH}$.

6. Sitting and conducting daily routine activities on the office desk via S2 (Figure 1b) for 1-hour at $\sim 3 \mathrm{ACH}$.

7. Sitting and conducting daily routine activities on the office desk via S2 (Figure 1b) for 1-hour at $\sim 9 \mathrm{ACH}$.

8. Sitting and conducting daily routine activities on the office desk via S2 (Figure 1b) for 1-hour at $\sim 4.5$ $\mathrm{ACH}$.

9. Sitting and conducting daily routine activities on the office desk via S2 (Figure 1b) for 1-hour with 2 inroom HEPA filters running.

Day 3-Relative humidity day ( O ACH):

1. 10-cough test via S1 set-up (Figure 1a) for 1 minute.

2. Speaking from a CDC approved passage (Supplemental document, appendix $A)^{21}$ at normal voice amplitude via S1 (Figure 1a) for 5 minutes.

3. Speaking from a CDC approved passage (Supplemental document, appendix $A)^{21}$ at higher voice amplitude via S1 (Figure 1a) for 5 minutes.

4. Sitting and conducting daily routine activities on the office desk via S2 (Figure 1b) for 1-hour.

5. Sitting and conducting daily routine activities on the office desk via S2 (Figure 1b) for 1-hour with 2 dehumidifiers running (low $\mathrm{RH}$ ).

6. Sitting and conducting daily routine activities on the office desk via S2 (Figure 1b) for 1-hour with 2 dehumidifiers running (low $\mathrm{RH}$ ).

7. Sitting and conducting daily routine activities on the office desk via S2 (Figure 1b) for 1-hour with 2 humidifiers running (high $\mathrm{RH}$ ).

8. Sitting and conducting daily routine activities on the office desk via S2 (Figure 1b) for 1-hour with 2 humidifiers running (high $\mathrm{RH}$ ).

At each entry, both a mouth and shallow nasal swab were self-collected from the study participant. Environmental samples were collected using flocked swabs (Harmony \#P25-3506-H), passive air settling 
plates (Millipore Sigma \#P5731-500EA), and active air samplers (ThermoFisher \#2900AA). Environmental swabs were collected from the participant's cell phone, computer, chair, and exhaust inlet. For walking on treadmill trials, samples from treadmill handrail, front rail, and bottom were collected. Flocked nylon swabs pre-moistened with DNA/RNA Shield (Zymo Research, Catalog \#R1100) were used to swab the sampling location in a zig-zag 'S' pattern for 15-20 seconds and then returned to a labeled $5 \mathrm{ml}$ tube containing $1 \mathrm{ml}$ of DNA/RNA Shield. Settling particulates were captured using both components (base and lid) of standard Petri dishes. Following the sampling period, both sides of the Petri dish (sampling area $\sim 110 \mathrm{~cm}^{2}$ ) were swabbed following the protocol described above for environmental swabs. Active air samples were collected using two AerosolSense samplers. The AerosolSense sampler works by drawing air into an accelerating slit impactor at a rate of $200 \mathrm{~L} /$ minute, causing particles to impact onto a collection substrate. Following the sampling period, the collection substrate was transferred to $1 \mathrm{ml}$ of DNA/RNA Shield using flame-sterilized forceps and transported back to a BSL-2 laboratory. Upon return to the laboratory, the capture media was briefly vortexed, then centrifuged for 2-minutes at 1,500 x g to remove all liquid from the collection substrate. Following centrifugation, the collection substrate was placed into biohazard and discarded appropriately.

\section{Molecular Analysis}

All protocols were performed in a Purifier Logic+ Class II, Type A2 biosafety cabinet (LabConco, Catalog \#302420001). Total RNA was extracted using the Quick-DNA/RNA Viral Magbead kit (Zymo Research, Catalog \#R2141). Nucleic acids were stored at $-80^{\circ} \mathrm{C}$ until downstream analysis could be performed. A $5 \mu \mathrm{l}$ spike-in of Escherichia coli MS2 bacteriophage was added to each extraction well to confirm the success of each RNA extraction. Additionally, a sample of nuclease free water was included with each batch of samples during extraction to serve as an extraction control. Samples underwent quantitative reversetranscription polymerase chain reaction (qRT-PCR) analysis using the TaqPath COVID-19 Combo Kit (Thermo Fisher Scientific, Catalog \#A47814) targeting the spike (S), nucleocaspid (N), and RNA-dependent RNA polymerase (RdRP/ORF1ab) genomic regions. Additionally, the assay also targets the Escherichia coli MS2 bacteriophage as an internal process control. The reaction mixtures included $5 \mu$ TaqPath 1-Step Multiplex Mastermix without ROX (Thermo Fisher Scientific, Catalog \#A28521), $9 \mu$ l nuclease-free water (Invitrogen, Catalog \#4387936), 1 l l COVID-19 Real Time PCR Assay Multiplex Mix (Thermo Fisher Scientific, Catalog \#A47814), and $5 \mu$ l of template RNA. Thermocycling was performed with the QuantStudio5 (Applied Biosystems). Samples were considered positive if amplification was observed in two of three genome targets

with a cycle threshold $\left(C_{T}\right)$ value less than or equal to $35\left(C_{T} \leq 35\right)^{32}$. Each qRT-PCR plate contained a positive RNA control and a no-template control (nuclease-free water) All controls performed as expected.

\section{Statistical Analyses}

Analyses were performed using the statistical programming environment $\mathrm{R}$. The correlation between observed $\mathrm{C}_{\mathrm{T}}$ values and other environmental parameters was conducted through the use of a generalized linear model. One-tailed paired t-test were used to identify statistical differences between categorical variables such as mean $\mathrm{C}_{\mathrm{T}}$ values and environmental parameters unless otherwise noted. Black solid horizontal line represents median in all box plots in this article. One tailed non-paired t-test was used to identify statistical differences for trials with outdoor air exchange rate of under $\sim 4.5 \mathrm{ACH}$ and above $\sim 9 \mathrm{ACH}$. 


\section{Financial Disclosure \& Competing Interests}

KGVDW has a company called Duktile that provides consulting related to healthy buildings and pathogen control. KGVDW also serves as a scientific advisor to EnviralTech, a company that conducts viral environmental surveillance and infection control. Neither Duktile nor EnviralTech played any role in the study design, data collection and analysis, decision to publish, or preparation of the manuscript. No other authors have any competing interests to disclose. This research was funded by Thermo Fisher Scientific under award number 4133V1. The funder provided the university with support in the form of salaries for all authors, equipment, and reagents but did not have any additional role in the study design, data collection and analysis, decision to publish, or preparation of the manuscript. However, per contractual obligations, the funder had the right to review the final manuscript for confidential information prior to submission.

\section{Data and code availability}

All data and code supporting this study and required to create the analyses are provided in Github, available at https://github.com/BioBE/RDM

\section{Declarations}

\section{Author contributions:}

KGVDW performed funding acquisition and managed the investigation team. KGVDW and HP conceived of project scope and methodology with input from LD and PFH. KGVDW and LD enrolled and consented study participants. DN worked with all other authors to set up modular room and all research instrumentation. HP, LB, LD, and AOM collected biological specimens. LB, LD, PFH, AOM performed laboratory analyses. HP performed data curation, data exploration, developed final analysis scripts, performed final analysis, and created visualizations with support from all authors. HP developed the original manuscript with direction and input from KGVDW. All authors provided manuscript revisions and edits on subsequent manuscript drafts and approved final manuscript.

\section{Acknowledgments}

The authors would like to thank all staff in the BioBE Center, including Garis Bowles, Georgia MacCrone, Jackson Mestler, Dan Richards, and Vincent Moore. The authors would like to thank countless individuals at the University of Oregon for helping to make this research design possible. The authors would also like to thank Dr. Richard Corsi, Dr. Siobhan Rockcastle, and Dr. Mark Fretz for their input during results analysis. Most importantly, we would like to thank all study participants for their commitment during a difficult period in their lives.

\section{References}


1. Coronavirus disease (COVID-19) - World Health Organization.

https://www.who.int/emergencies/diseases/novel-coronavirus-2019?adgroupsurvey=

\{adgroupsurvey\}\&gclid=CjwKCAjw7rWKBhAtEiwAJ3CWLHGbvztXUoXWCMAym2mJHBi1Ut6YIC4qUYhyDB93pMnaBYUQAI5mhoCXOsQAvD_BwE.

2. Anderson, E. L., Turnham, P., Griffin, J. R. \& Clarke, C. C. Consideration of the aerosol transmission for COVID-19 and public health. Risk Anal. 40, 902-907 (2020).

3. Ma, J. et al. Coronavirus disease 2019 patients in earlier stages exhaled millions of severe acute respiratory syndrome Coronavirus 2 per hour. Clin. Infect. Dis. 72, e652-e654 (2021).

4. Zhou, L. et al. Breath-, air- and surface-borne SARS-CoV-2 in hospitals. J. Aerosol Sci. 152, 105693 (2021).

5. Santarpia, J. L. et al. The size and culturability of patient-generated SARS-CoV-2 aerosol. J. Expo. Sci. Environ. Epidemiol. 1-6 (2021).

6. Tang, J. W. et al. Dismantling myths on the airborne transmission of severe acute respiratory syndrome coronavirus-2 (SARS-CoV-2). J. Hosp. Infect. 110, 89-96 (2021).

7. Hoffmann, M. et al. SARS-CoV-2 cell entry depends on ACE2 and TMPRSS2 and is blocked by a clinically proven protease inhibitor. Cell 181, 271-280.e8 (2020).

8. Flaxman, S. et al. Estimating the effects of non-pharmaceutical interventions on COVID-19 in Europe. Nature 584, 257-261 (2020).

9. Azimi, P., Keshavarz, Z., Cedeno Laurent, J. G., Stephens, B. \& Allen, J. G. Mechanistic transmission modeling of COVID-19 on the Diamond Princess cruise ship demonstrates the importance of aerosol transmission. Proc. Natl. Acad. Sci. U. S. A. 118, e2015482118 (2021).

10. Parhizkar, H., Van Den Wymelenberg, K., Haas, C. \& Corsi, R. A quantitative risk estimation platform for indoor aerosol transmission of COVID-19. bioRxiv (2021) doi:10.1101/2021.03.05.21252990.

11. Qian, H. Indoor transmission of SARS-CoV-2. Indoor Air 12766 (2020).

12. Morawska, L. et al. A paradigm shift to combat indoor respiratory infection. Science 372, 689-691 (2021).

13. Coleman, K. K. et al. Viral load of SARS-CoV-2 in respiratory aerosols emitted by COVID-19 patients while breathing, talking, and singing. bioRxiv 2021.07.15.21260561 (2021) doi:10.1101/2021.07.15.21260561.

14. Dietz, L. et al. 2019 novel Coronavirus (COVID-19) pandemic: Built environment considerations to reduce transmission. mSystems 5, (2020).

15. Dabisch, P. et al. The influence of temperature, humidity, and simulated sunlight on the infectivity of SARS-CoV-2 in aerosols. Aerosol Sci. Technol. 55, 142-153 (2021). 
16. Doremalen $\mathrm{N}$ et al. Aerosol and surface stability of SARS-CoV-2 as compared with SARS-CoV-1. (2020).

17. Kim, S. W., Ramakrishnan, M. A., Raynor, P. C. \& Goyal, S. M. Effects of humidity and other factors on the generation and sampling of a coronavirus aerosol. Aerobiologia (Bologna) 23, 239-248 (2007).

18. Chan, K. H. et al. The effects of temperature and relative humidity on the viability of the SARS Coronavirus. Adv. Virol. 2011, 734690 (2011).

19. Li, Y. et al. Role of ventilation in airborne transmission of infectious agents in the built environment - a multidisciplinary systematic review. Indoor Air 17, 2-18 (2007).

20. de Man, P. et al. Outbreak of Coronavirus disease 2019 (COVID-19) in a nursing home associated with aerosol transmission as a result of inadequate ventilation. Clinical infectious diseases: an official publication of the Infectious Diseases Society of America vol. 73 170-171 (2021).

21. https://www.cdc.gov/niosh/npptl/stps/pdfs/RCT-APR-0067-508.pdf.

22. Fairbanks, G. Voice and Articulation Drillbook. Laryngoscope 51, 1141 (1941).

23. Jia, Y. Real-Time PCR. in Methods in Cell Biology (ed. Conn, P. M.) vol. 112 55-68 (Elsevier, 2012).

24. Asadi, S. et al. Aerosol emission and superemission during human speech increase with voice loudness. Sci. Rep. 9, 2348 (2019).

25. Allen, J. G. \& Ibrahim, A. M. Indoor air changes and potential implications for SARS-CoV-2 transmission. JAMA 325, 2112-2113 (2021).

26. Dietz, L. et al. Correction for Dietz et al., "2019 Novel Coronavirus (COVID-19) Pandemic: Built Environment Considerations To Reduce Transmission." mSystems 5, (2020).

27. Klompas, M., Baker, M. A. \& Rhee, C. Airborne transmission of SARS-CoV-2: Theoretical considerations and available evidence. JAMA 324, 441-442 (2020).

28. Horve, P. et al. Longitudinal analysis of built environment and aerosol contamination associated with isolated COVID-19 positive individuals. (2021) doi:10.21203/rs.3.rs-861942/v1.

29. Hänel, G. Humidity effects on gravitational settling and Brownian diffusion of atmospheric aerosol particles. Pure Appl. Geophys. 115, 775-797 (1977).

30. Chaudhuri, S., Basu, S. \& Saha, A. Analyzing the dominant SARS-CoV-2 transmission routes toward an ab initio disease spread model. Phys. Fluids (1994) 32, 123306 (2020).

31. Rocha, A. L. S. et al. Fomites and the environment did not have an important role in COVID-19 transmission in a Brazilian mid-sized city. Sci. Rep. 11, 15960 (2021).

32. https://www.fda.gov/media/136112/download. 
Figures

a

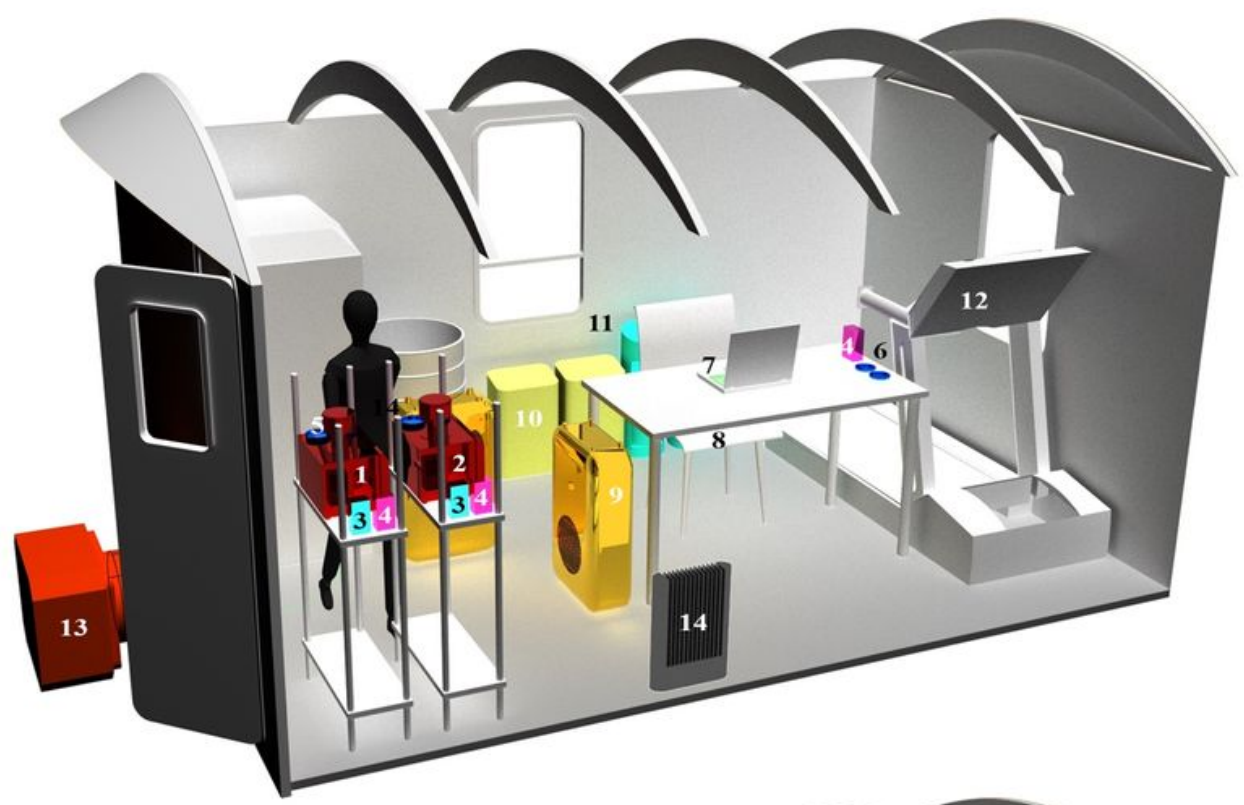

b

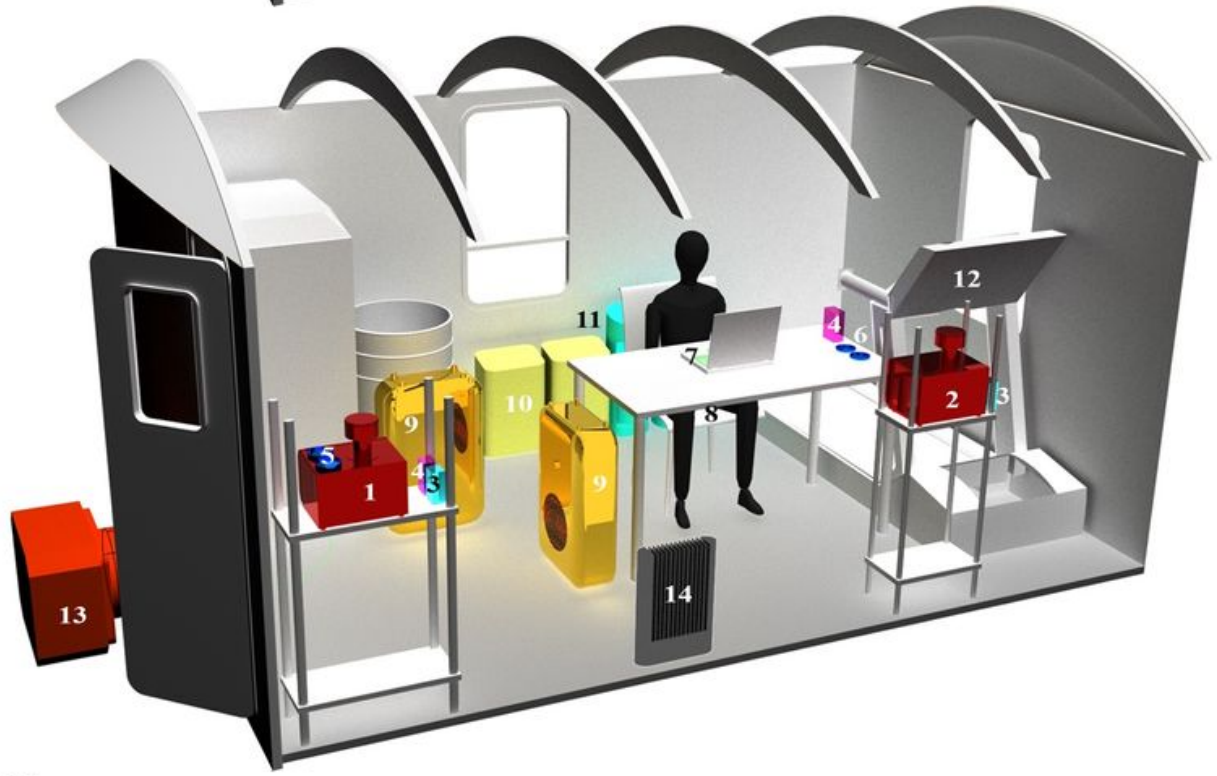

Legend

1- Far field AerosolSense

2- Close field AerosolSense

3 - Particle counter

4 - $\mathrm{CO}_{2}$ onset

5 - Far field settling plate

6 - Close field settling plate

7 - Computer

8 - Chair

9 - In room HEPA filters

10-Dehumidifiers

11- Humidifiers *

12 -Treadmill

14 - Heaters *

* Only one object of this kind is visible in this figure

\section{Figure 1}

Rapid deployment modular unit (RDM), a) higher expiratory trials (S1), b) regular trials (S2) 
a

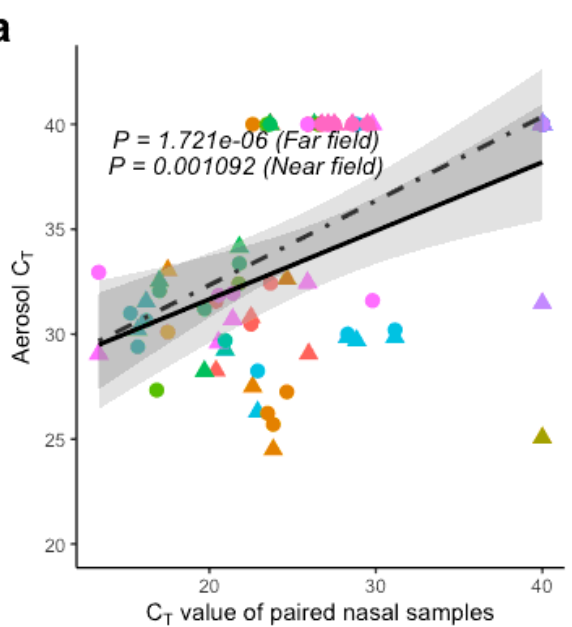

C

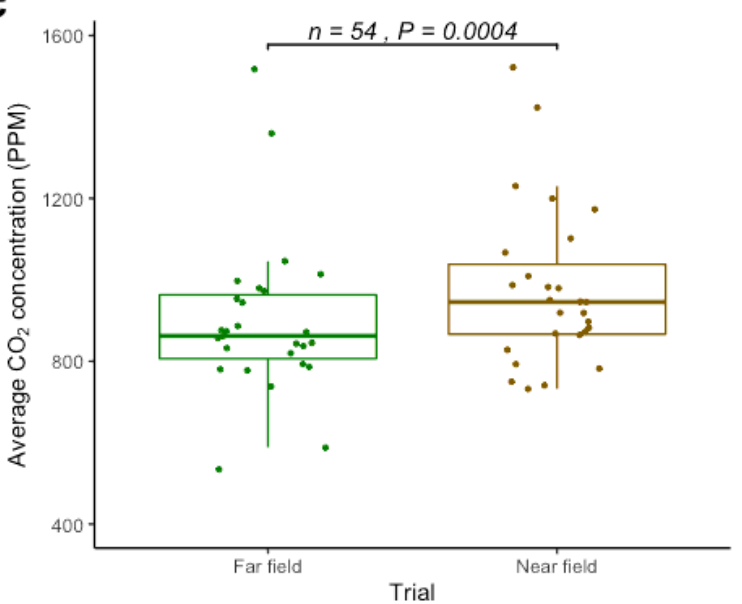

b

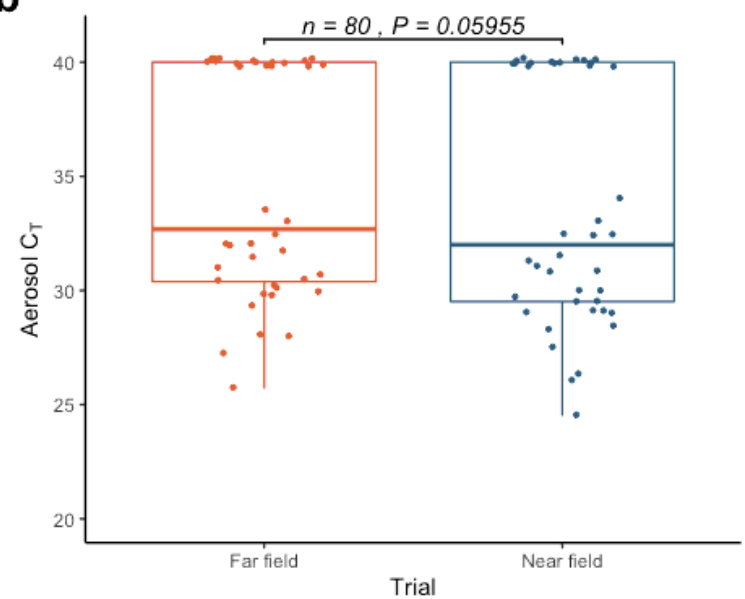

d

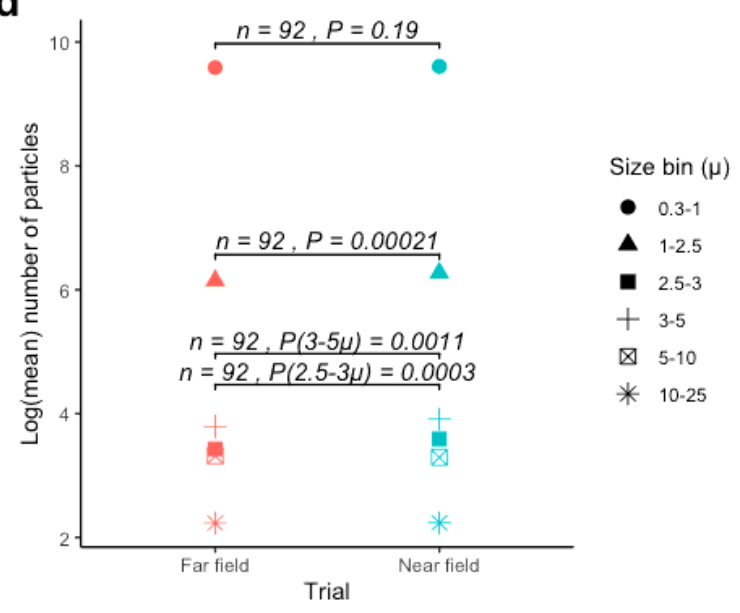

e

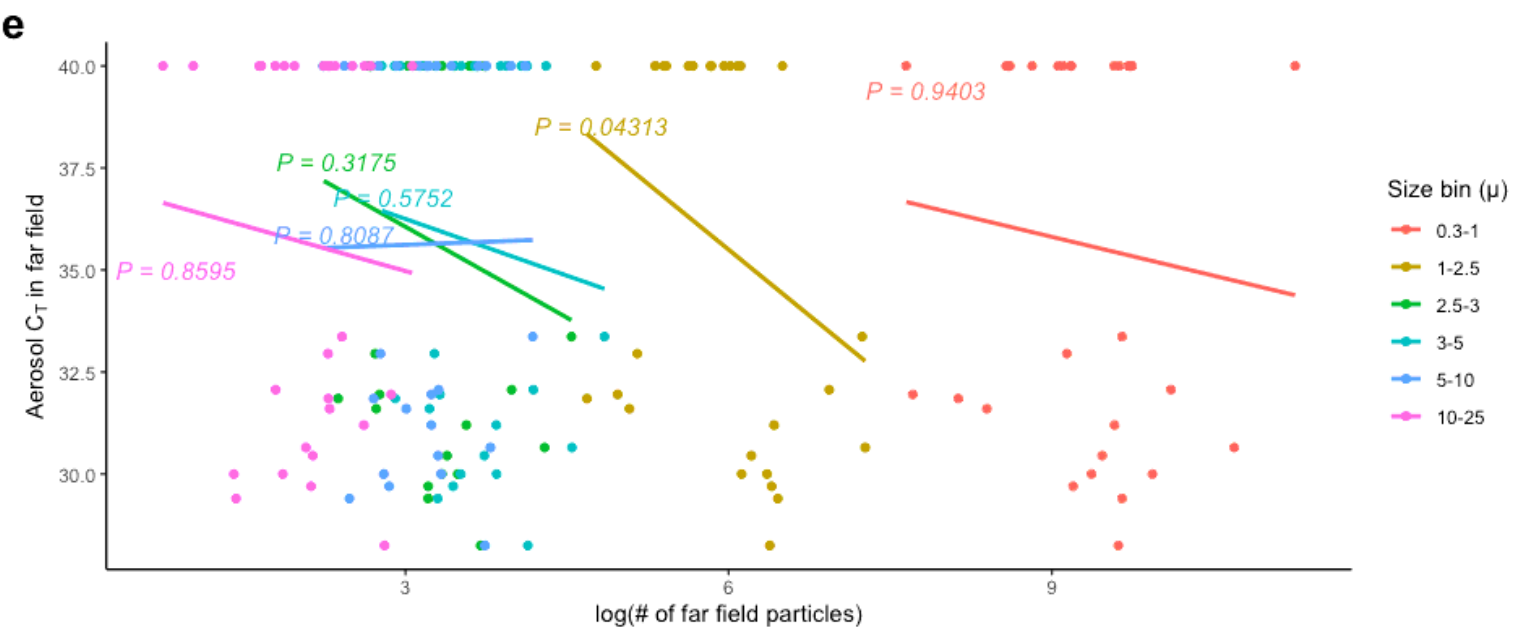

Figure 2

a) The correlation of near field $(1.2 \mathrm{~m})$ or far field $(3.5 \mathrm{~m})$ aerosol viral loads (RNA) with corresponding human nasal samples during routine trials $b$ ) comparison of near field and far field aerosol viral loads for routine trials, c) comparison of mean $\mathrm{CO} 2$ concentrations in the near field and far field for routine trials, d) paired ttests for all particle size bins at near field and far field for routine trials, e) correlation between mean far field aerosol vial loads and the corresponding mean concentration of far field particles for routine trials. 
a

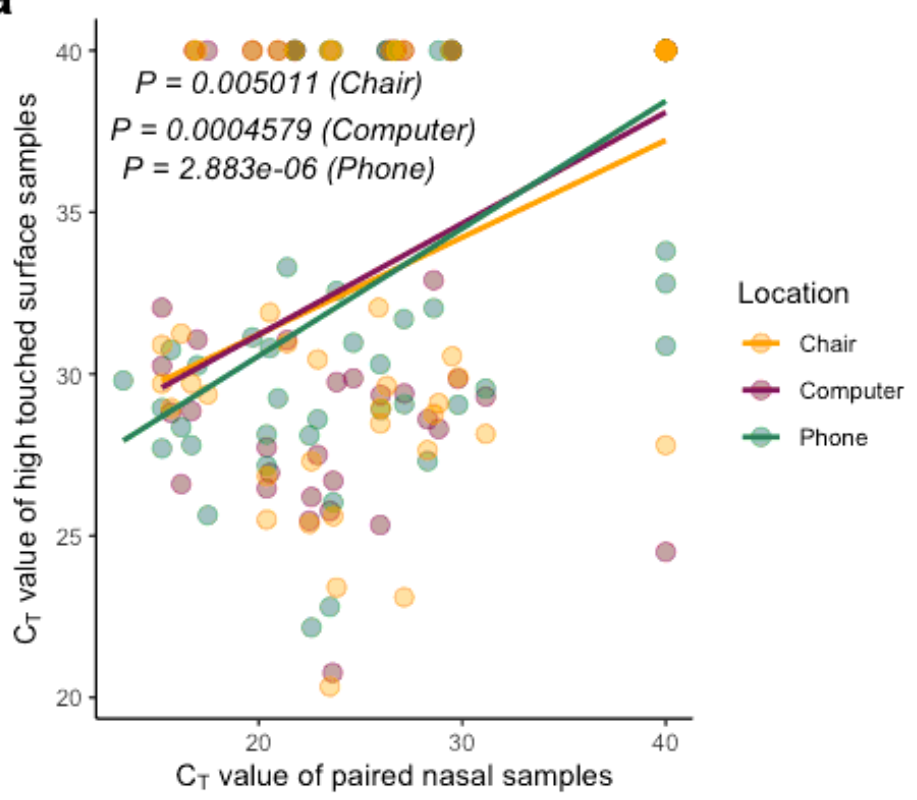

b

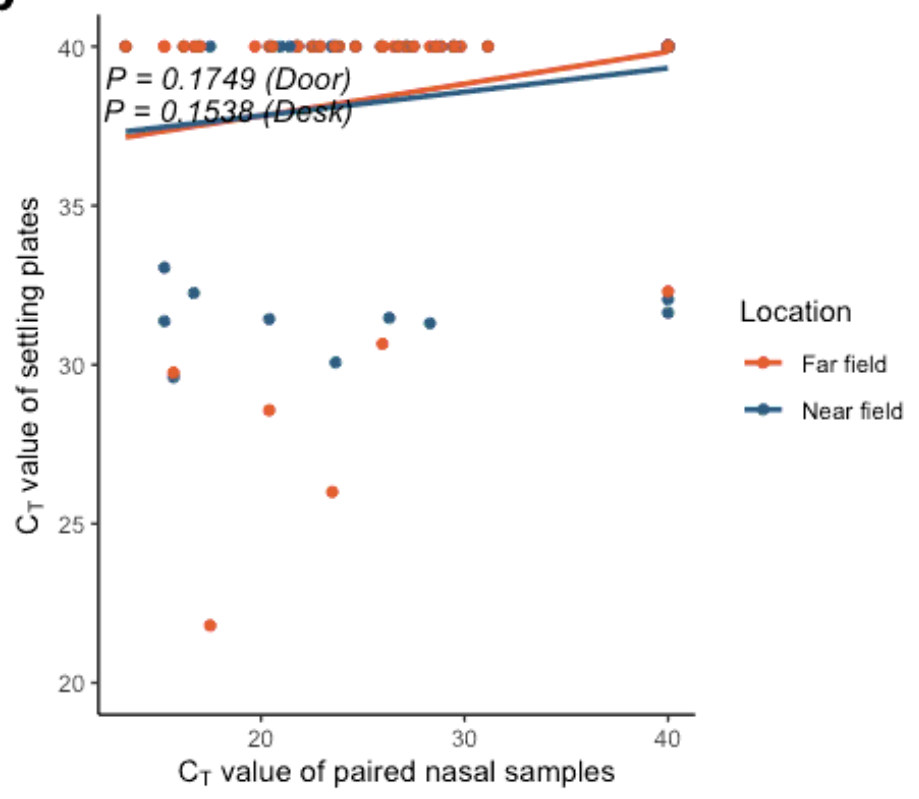

C

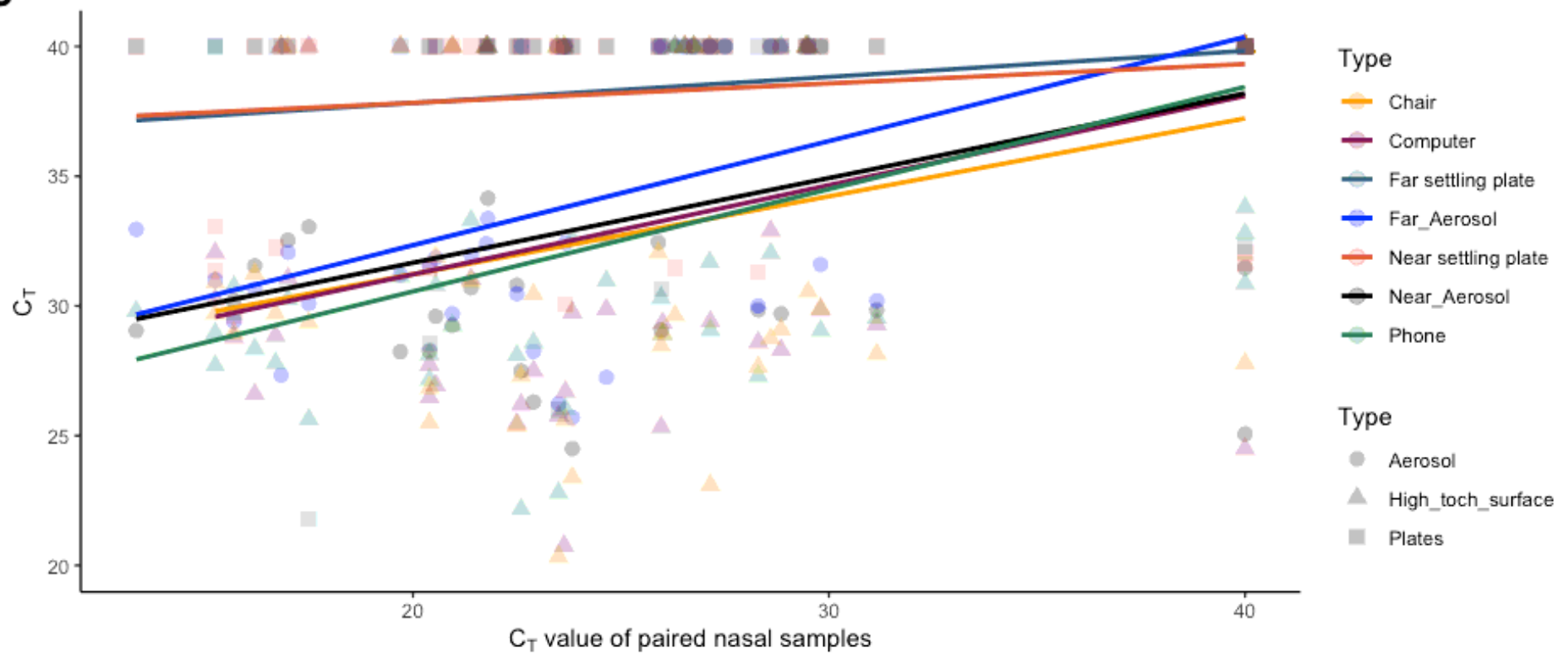

Figure 3

a) viral load (RNA) on each high-touch surface relative to paired nasal samples, b) viral load (RNA) on settling plates at near and far field relative to paired nasal samples, c) The correlation of each sample type (Aerosol, high touched surfaces, and settling plates) to paired nasal sample. 
a

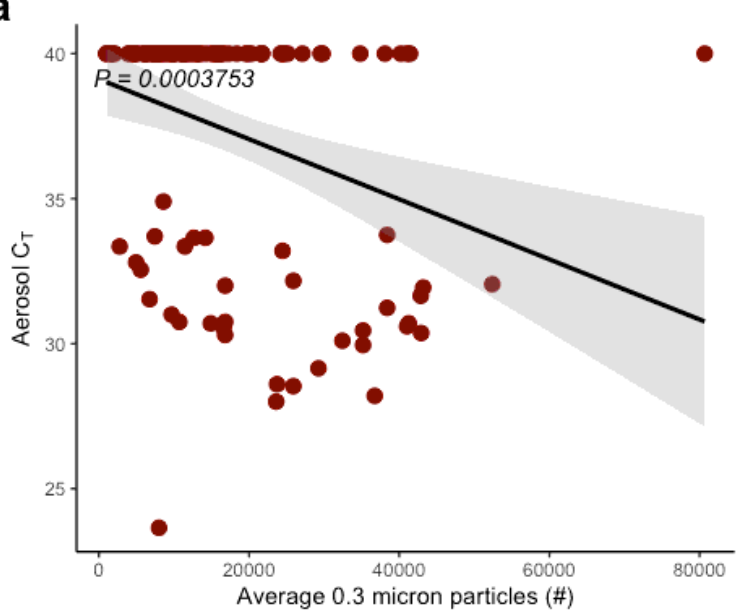

C

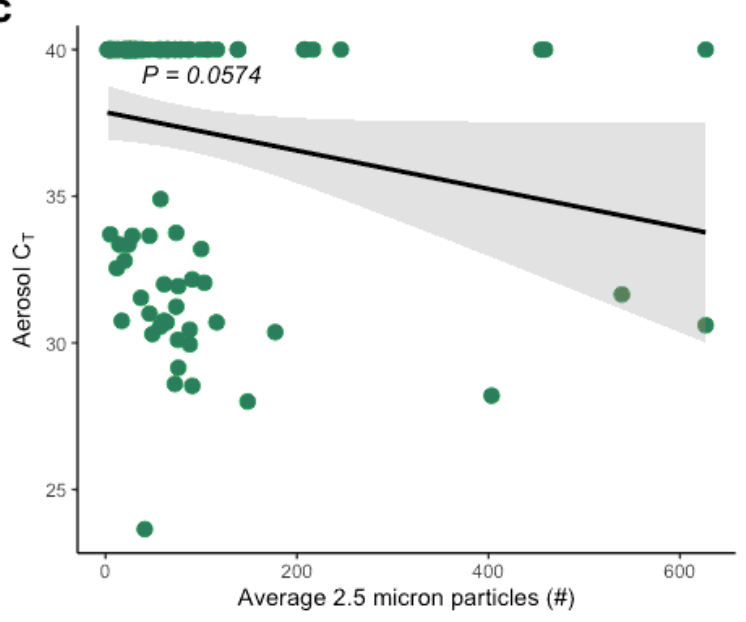

e

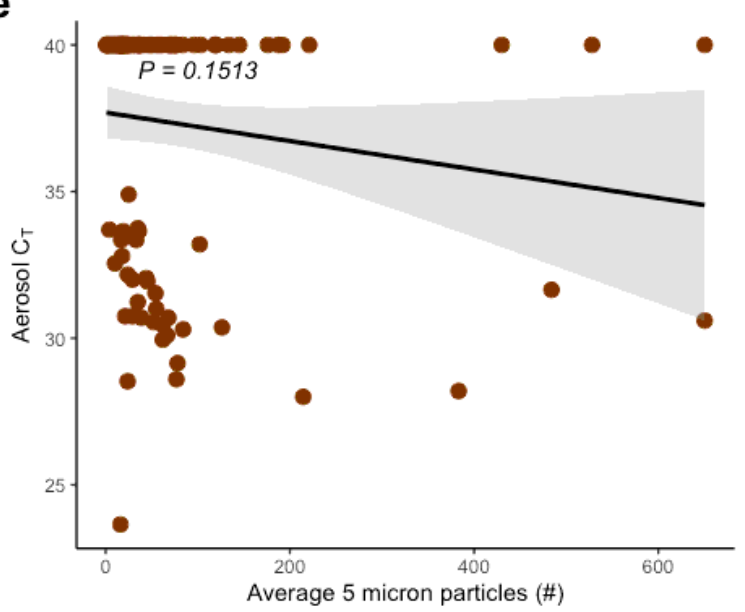

b

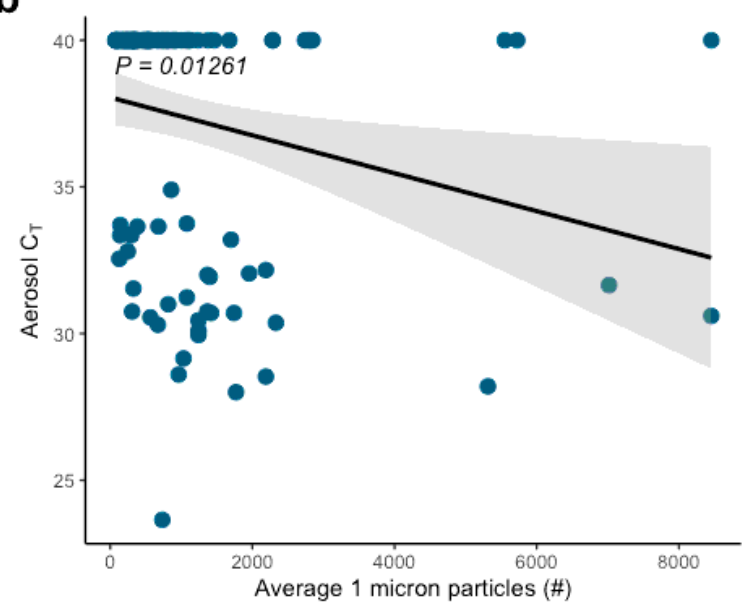

d

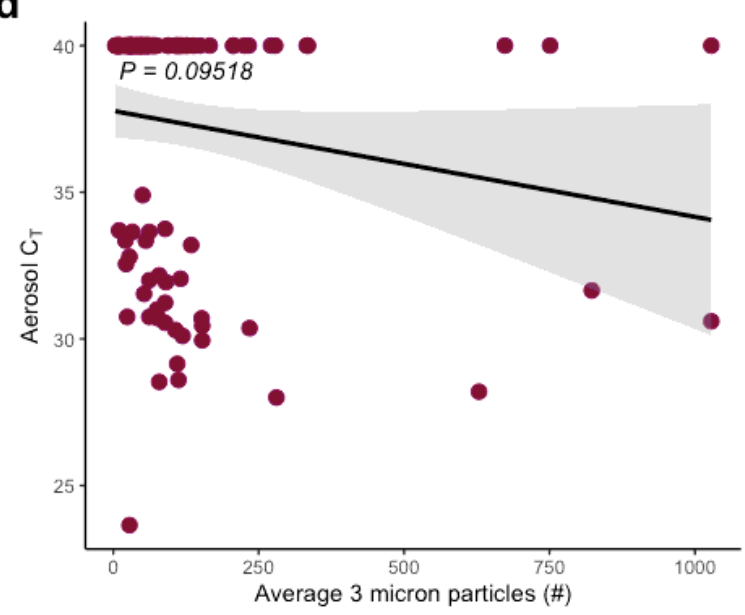

f

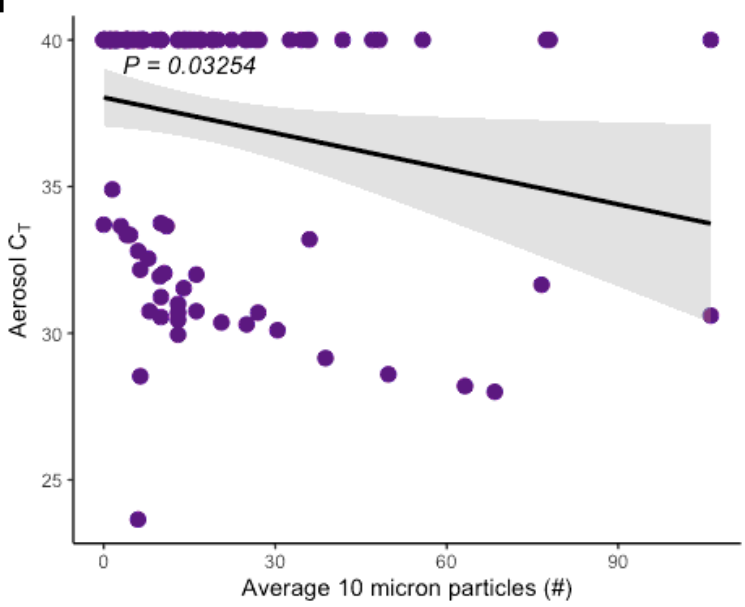

Figure 4

Linear correlation between CT value and particles for a) 0.3-1 $\mu$ m particles, b) 1-2.5 $\mu \mathrm{m}$ particles, c) 2.5-3 $\mu \mathrm{m}$ particles, d) 3-5 $\mu \mathrm{m}$ particles, e) 5-10 $\mu \mathrm{m}$ particles, and f) 10-25 $\mu \mathrm{m}$ particles. 
a

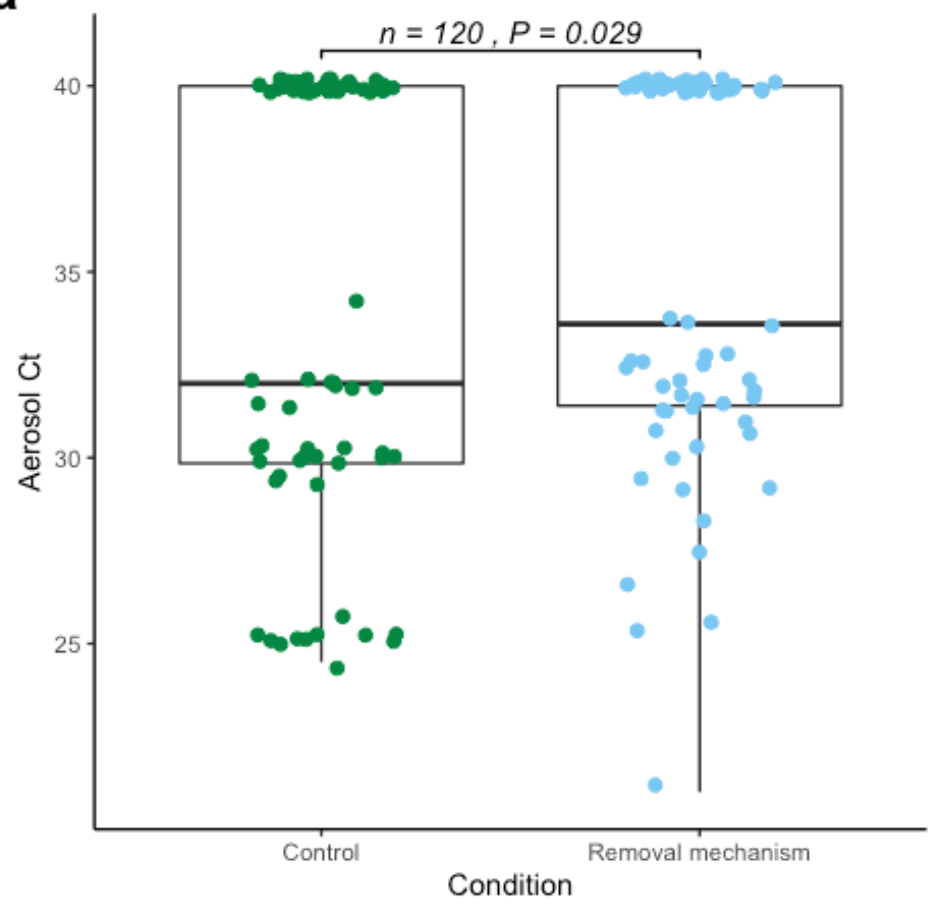

C

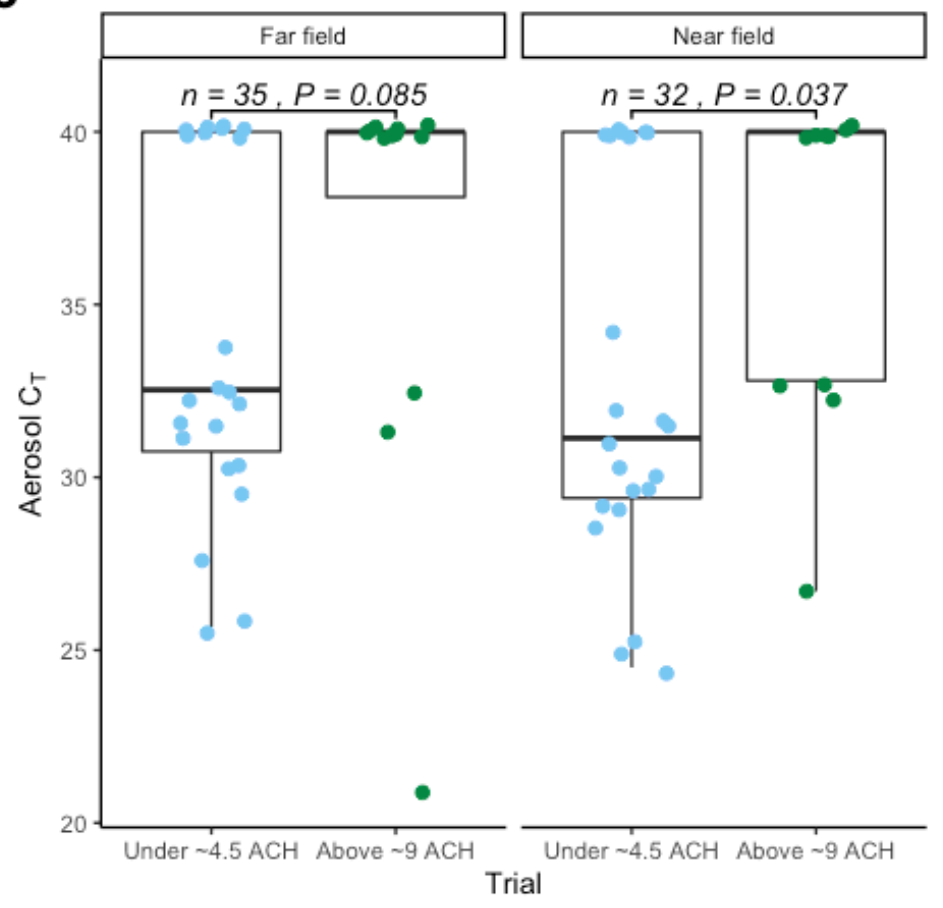

b

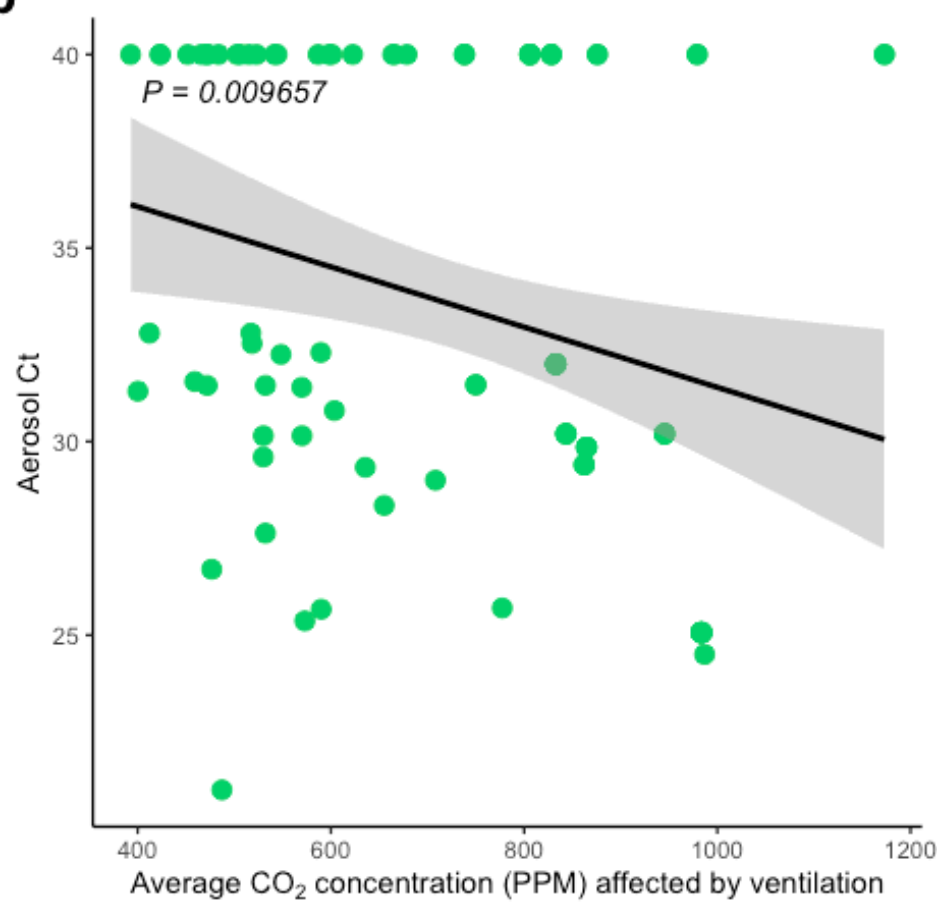

d

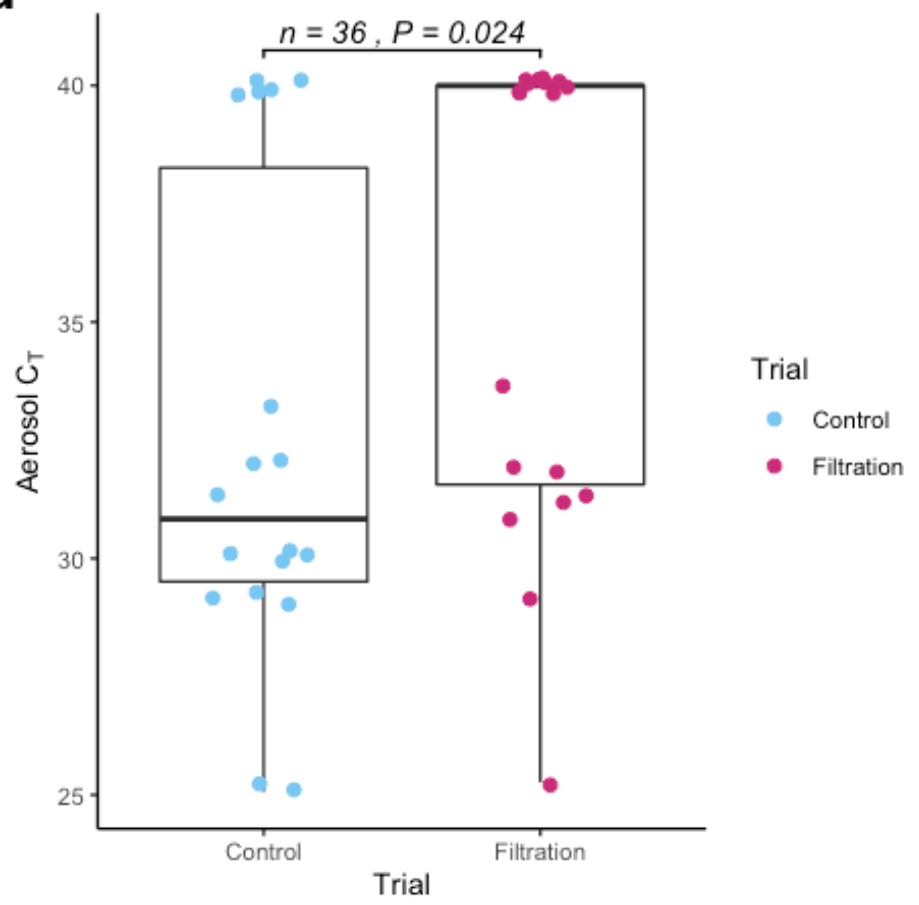

\section{Figure 5}

The impact of ventilation and filtration on CT value of aerosol samples, a) match paired comparison between trials with removal mechanism trials (filtration and ventilation) and control trials with $\sim 0 \mathrm{ACH}, \mathrm{b}$ ) linear correlation between aerosol CT value and paired mean $\mathrm{CO} 2$ concentration affected by only ventilation (same physical activities), c) Comparison of aerosol CT for ventilation trials of under $\sim 4.5 \mathrm{ACH}$ and above $\sim 9 \mathrm{ACH}$ in near field and far field, d) match paired comparison of aerosol CT for trials with in-room HEPA filtration and corresponding control trials with $\sim 0 \mathrm{ACH}$. 
a

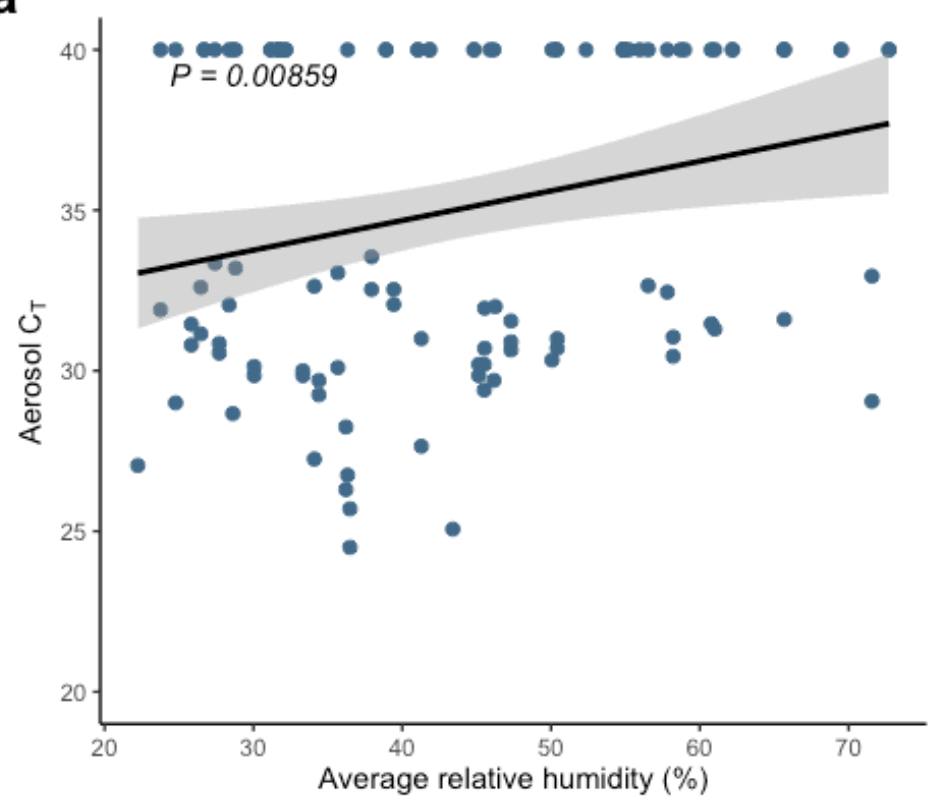

C

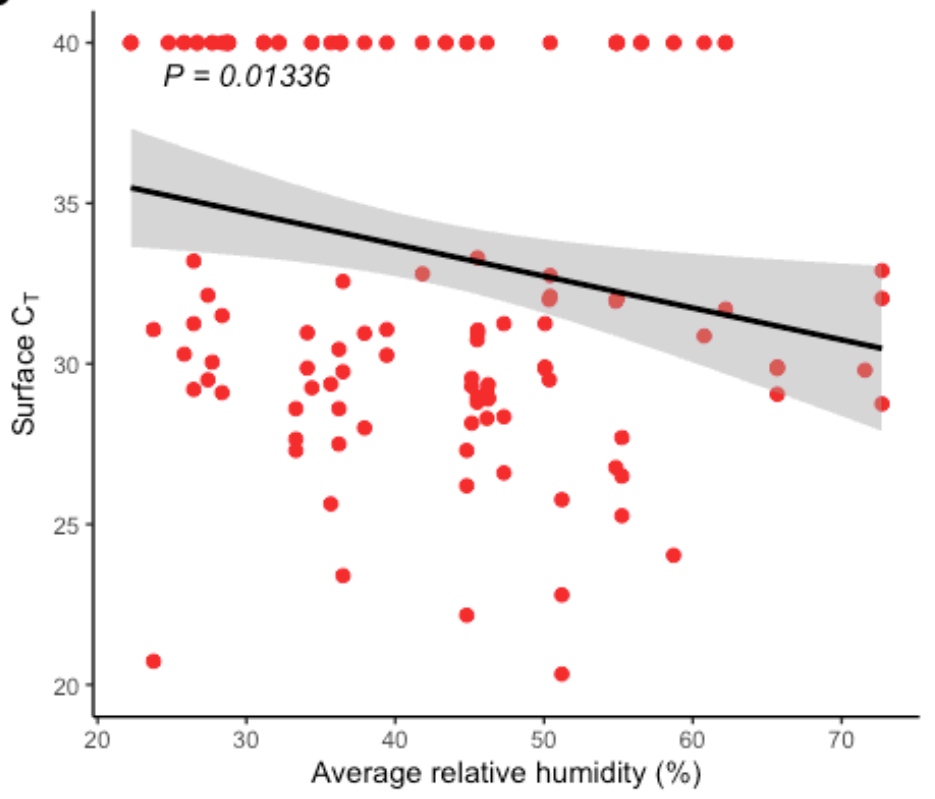

b

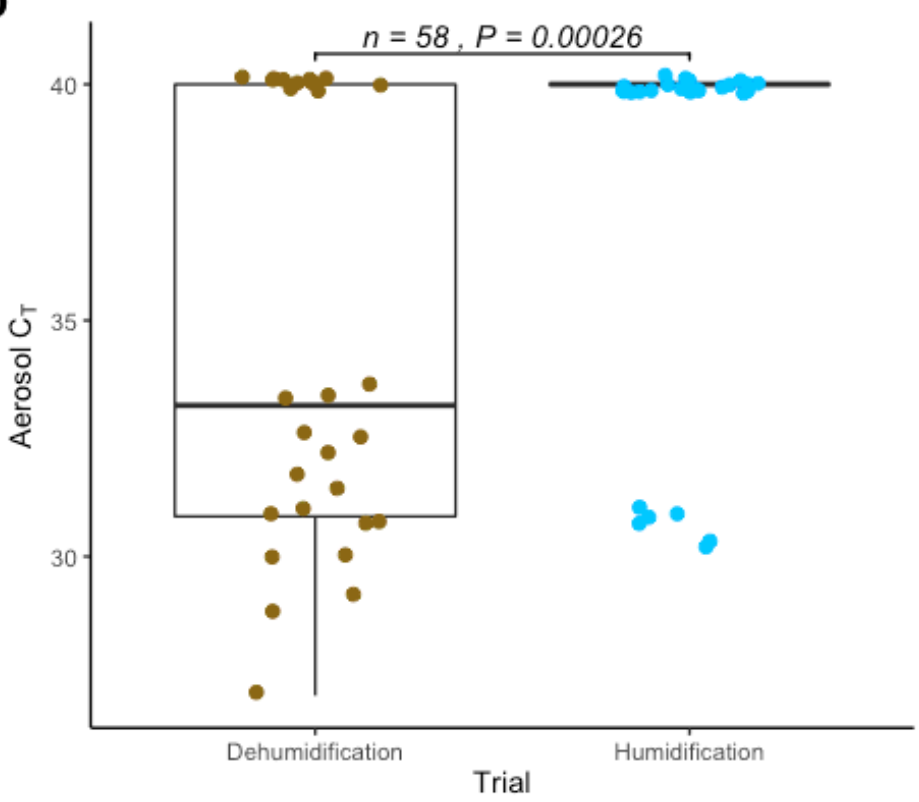

d

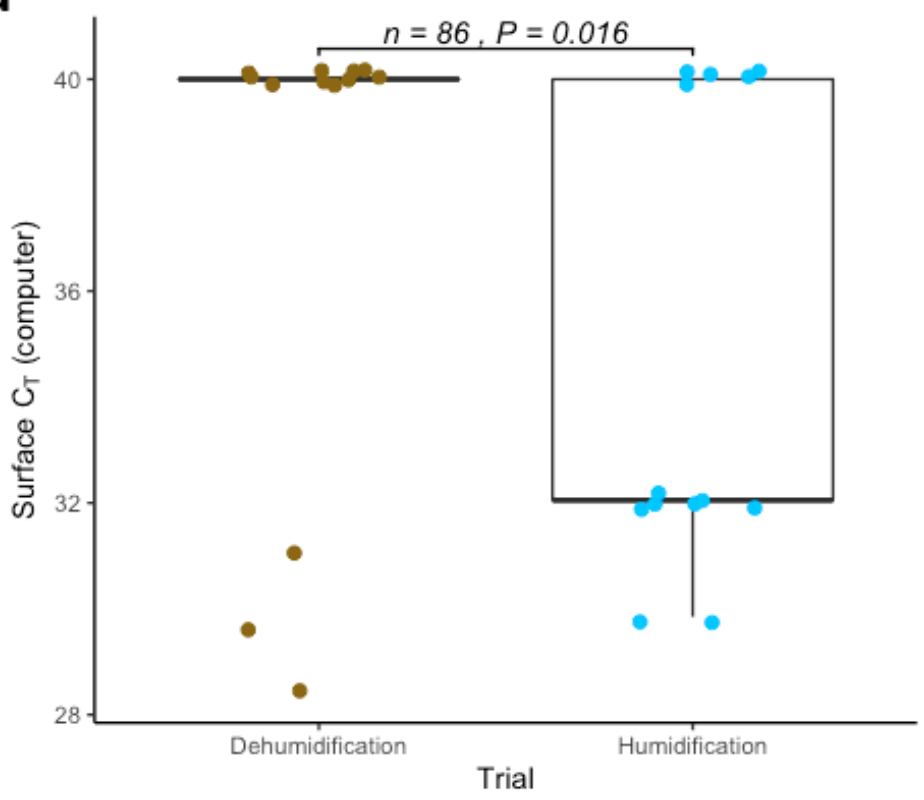

Figure 6

a) Correlation between aerosol CT value and mean relative humidity among dehumidification, humidification, and control trials b) paired comparison of aerosol CT between Dehumidification and Humidification trials, c) Correlation between surface CT value and mean relative humidity among dehumidification, humidification, and control trials, d) ) paired comparison of select surface (computer) CT between Dehumidification and Humidification trials.

\section{Supplementary Files}

This is a list of supplementary files associated with this preprint. Click to download. 
- SupplementaldocumentRDM.docx

Page 21/21 